\title{
Reassessing Blacklist Era Television: Civil Libertarianism in You Are There, The Adventures of Robin Hood, and The Buccaneers
}

\section{Andrew Paul}

In the early fifties, the entertainment industry blacklist that had begun in Hollywood in 1947 spread to the television industry in New York City. Three former FBI agents formed the anticommunist organization American Business Consultants and in 1950 published Red Channels, a list of 151 writers, artists, and entertainment and media industry members that they suspected of being either communists, former communists, or one-time fellow travelers. The television and radio networks, afraid that employing anyone on the list would make them lose sponsors, fired actors and industry workers en masse, with no apparent prodding or influence by the state agencies. ${ }^{1}$

There was no great dividing line between the film industry and that of television in terms of the blacklist. The American Business Consultants outed film and television workers alike. But whereas scholars have seen the Hollywood blacklist either as an impediment to progressive filmmaking, or have written off the possibility that the old film studio system could ever produce left-liberal films in the first place, those that have written about television have been more likely to cite their medium of study as a site of resistance. In Cold War, Cool Medium, historian Thomas Doherty argues that television constituted a form that "utter[ed] defiance and encourage[d] resistance."2 More recently, historian Andrew Falk has argued that television nurtured a progressive form of cultural diplomacy. ${ }^{3}$ 
I argue that even though television allowed blacklisted writers to work using pseudonyms or "fronts," their ability to challenge the dominant discourses of the cold war was circumscribed by libertarianism. Powerful strains of this individualistic ideology emerged not only from conservatives, but from liberals and leftists as well. Like their counterparts in the film industry, left-liberal television writers might have previously written in the lexicon of the Popular Front, a social-democratic coalition of liberals and leftists that thrived from the late thirties and early forties. But after the blacklist came, these same writers were more likely to adopt a civil libertarian rhetoric that emphasized individual liberties over matters of social justice. ${ }^{4}$

In other words, Doherty and others are not altogether wrong in seeing effective liberal antiauthoritarian or antidemagogic discourses emerge from the television news media and entertainment industry during the 1950s. ${ }^{5}$ Where my approach diverges is in seeing the "McCarthyist" state as a means of governance rather than its origin. Anticommunism worked its way through the state, but it didn't begin or end there. With this in mind, we discover that critiques of the state - that is, charges of fascism, totalitarianism, witch hunts, show trials, and blacklists - did not necessarily work in favor of the social democratic philosophies that had been the target of various red scare progenitors in the first place. In fact, in invoking the concept of "McCarthyism," the historical subjects of this article (as well as many contemporary figures) have had the tendency to ascribe a large and diverse political phenomenon to the words and actions of one man. This reified a focus on the state that elides the more complex ways in which anticommunism worked symbiotically with various forms of liberal governance rather than adversarially. ${ }^{6}$

This article examines three television shows of the blacklist era: You Are There (1953-57), The Adventures of Robin Hood (1955-58), and The Buccaneers (1956-57). These shows are notable because they were relatively popular, and because their producers staffed the shows almost exclusively with blacklisted writers. In each case, the writers of these shows expressed the belief that they were combating red scare culture with their choices of plots. What is troublesome is historians and television scholars have taken reminiscences of the writers at face value. Their stories provide vehicles for us to examine the discourse of the period more critically, with an eye not only toward how the medium of television perhaps moved "left" or "right," but rather to how the very conceptions of what constituted these categories shifted during this period of fear. Just as in Hollywood, the discourse of civil libertarianism provided leftliberals a means to fight the forces of their own marginalization. But at the same time, civil libertarianism replaced the language that was common in Popular Front organizations of the 1940s, language that advocated political justice as well as structural economic justice, and that understood socioeconomic and racial problems to be intersectional. 


\section{The Televisual "Guerrilla Warfare" of You Are There}

A viewer in 1953 might be have been startled to find serious CBS news reporters interviewing figures such as the Spanish conquistador Hernan Cortes on primetime television, with Walter Cronkite providing additional commentary from behind his anchor desk. But such was the format of the popular weekly series You Are There (1953-57), which depicted a different historical event each week, based around a format in which contemporary journalists interacted with men and women from diverse historical moments. The show was critically acclaimed and shown in classrooms across the country.

Few were aware that the show was written by blacklisted writers. Behind the scenes, Abraham Polonsky, Walter Bernstein, and Arnold Manoff submitted their scripts with other peoples' names. These "fronts" were used to help terminated writers find work. The writers did not see the opportunity to write for You Are There as just a means to an income, however. They seized the chance to narrate historical events on television as an opportunity to conduct "guerrilla warfare" against what Polonsky and many others referred to as "McCarthyism."

Neither Polonsky nor Manoff had intended to pursue employment in the television industry, and Bernstein had been writing television for only a brief period of time. Prior to that he wrote for the New Yorker after working for Yank, an Army newspaper, during World War II. ${ }^{8}$ Manoff, after having published a novel, had success in writing for the New York theater. ${ }^{9}$ And Polonsky had achieved success in academia as well as popular art, having taught English and practiced law in the thirties, contributed scripts to the radio show The Goldbergs, published a novel, and written two feature Hollywood films, one of which he directed. ${ }^{10}$

Bernstein, Polonsky, and Manoff would each find themselves blacklisted in the entertainment industries. Bernstein's name appeared in Red Channels in June $1950 .{ }^{11}$ Polonsky was subpoenaed by the House Un-American Activities Committee the same year, appearing before the committee as an "unfriendly witness" in April of 1951. ${ }^{12}$ Polonsky refused to recant and "name names," the ritual that was required of an accused radical to clear his or her reputation and work again, but others did; elsewhere a communist under investigation named Arnold Manoff to the committee. ${ }^{13}$

Bernstein began writing scripts under a pen name, Paul Baumann. But television network and advertising agency executives quickly became aware of this practice among blacklisted writers. ${ }^{14}$ They increasingly called for story conferences, in which writers were brought in to discuss their work. Charles Russell, the producer of the CBS television show Danger, for which Bernstein was writing, was forced to get creative to aid his blacklisted employee. When asked why Baumann could not attend a story conference, Russell replied that he was living a secluded life atop a mountain in Colorado and had no access to a telephone. In another instance, Russell told CBS that Baumann had gone to Switzerland for treatment of a rare tropical disease. As using pseudonyms quickly became 
impossible for television writers, the fictional Baumann's disease proved fatal and he passed away in a Swiss hospital. ${ }^{15}$

Eager to continue sending Danger scripts to Russell, Bernstein devised the "front" system, under which he enlisted real people who offered their names to put on Bernstein's scripts, for a percentage of the earnings in return. ${ }^{16}$ After Manoff and Polonsky left Los Angeles for New York, having testified and refused to name names, Bernstein introduced them to Russell, and by November of 1951, all three writers were contributing scripts to Danger under the names of fronts. ${ }^{17}$ About a year later, Russell was asked by CBS to develop a television version of You Are There, which ran as a radio program from 1947 to $1950 .{ }^{18}$ According to Bernstein, the three writers saw You Are There as an opportunity to "take over a whole show," so that, unlike with Danger, they would not have to compete with other, nonblacklisted writers. It also offered them jobs that suited their literary styles; "there was no need to make up stories with unhappy endings," recalls Bernstein, "history would provide more than enough."19

Russell had no apparent interest in the potential for political content in You Are There. ${ }^{20}$ But for Bernstein, Polonsky, and Manoff, You Are There offered an opportunity for them to narrate history in a specific way. "In that shameful time of McCarthyite terror, of know-nothing attempts to deform and defile history, to kill any kind of dissent," Bernstein recalls, "we were able to do shows about civil liberties, civil rights, artistic freedom, [and] the Bill of Rights." ${ }^{21}$ Executive producer and anticommunist William Dozier gave Russell a list of topics that he wanted the show to address, but Russell and the writers picked only the topics that interested them and supplemented the list with their own ideas. They agreed that their history had to be accurate, and that they could not write outright propaganda, but that by emphasizing conflict and what Polonsky called the "social contradictions" of history, the show could bring politics to television in a manner that had not been done before. ${ }^{22}$ "You don't have to lie or change the facts of history," said Polonsky, "but you have to be able to select them properly." Polonsky, Bernstein, and Manoff sought to interpret history in light of their own times and to employ history as social action. As if to underscore the relation of history to the present to make You Are There more politically potent, each and every show ended with Cronkite's sign off, penned by Polonsky: "What sort of day was it? A day like all days, filled with those events that alter and illuminate our time ... and you were there."

\section{You Are There and the Politics of the Blacklist}

Looking back, the most recognizable politics of You Are There is its antiMcCarthyism. In episode after episode, the writers of You Are There chose to narrate the stories of individuals who, for one reason or another, had become political or cultural pariahs because of their assumedly virtuous beliefs or principles. In shows about Galileo, Socrates, Joan of Arc, and John Milton, histori- 
cal figures showed steely resolve as they faced condemnation and punishment from authority figures.

These episodes were rife with allegorical allusions to the red scare of the early fifties, and they provide insight into the feelings of victimization and martyrdom that the blacklistees felt. One such episode, "The Execution of Joan of Arc," aired on March 1, 1953, one month after the show premiered. ${ }^{23}$ As the Earl of Warwick is being interviewed by the off-camera newsman, he calls Joan of Arc a "traitor to the church." The newsman counters, "She led your people to victory," to which the Earl replies, "but this girl is nothing but a witch," evoking the anticommunist accusations that came so soon after the era of the Popular Front and the U.S.-Soviet alliance of World War II. Later in the Polonskypenned episode, a bishop interrogates Joan of Arc, demanding, "You must declare that you have been treasonous." He asks that she renounce everything heretical that she has said, and he finally adds, "And you must tell who aided and abetted you." Joan, of course, refuses to recant or to "name names," and she is burned at the stake, after which Cronkite's narrative summation of the episode leaves no doubt as to where the writers' sympathies lay. "The fact is that Joan of Arc was right," he concludes, "and those who condemned her were wrong."

"The Crisis of Galileo," which aired April 19, 1953, and was also written by Polonsky, reveals similar motifs. The episode follows Galileo Galilei's recantation of his heliocentric model of the universe, in response to the Catholic Inquisition. In an interview with one of Galileo's students, the newsman asks him what the effect of Galileo's recantation would be. In another allusion to the act of naming names, the student responds, "It will make him look like a fool and a coward." He continues: "there can be no progress in the world ... without freedom of the mind, freedom of thought and of work." After Galileo recants to the Holy Office of the Inquisition, he returns to the Tuscan embassy, puts his head on the table, and cries.

Arnold Manoff's script, "The First Salem Witch Trial," which aired on March 29, 1953, was perhaps the most notably allegorical to television viewers. Arthur Miller's play The Crucible had opened in January, and Miller's intentions in critiquing the red scare through the story of the Salem witchcraft trials were a matter of public record. ${ }^{24}$ So when You Are There performed the witchcraft trials, focusing on the trial of Bridget Bishop, the first alleged witch to go before a jury, Variety magazine noted that the show "presented a powerful documentary for our times," and that it "underlined in strikingly dramatic terms the lethal threat of false accusations and mass hysteria." The review made note of the similarities in source material to Miller's play and lauded You Are There for not "spelling out" the allusion to contemporary events. ${ }^{25}$ The episode closes with some wishful thinking; Cronkite at his news desk pronounced, "As madness took hold, so did a deep shame," a declaration intended to underscore for the American people the injustice of the anticommunist hysteria.

These episodes are noteworthy for the way in which they promoted the value of civil liberties and used historical narratives as allegories for the era of 
McCarthyism. But in other episodes, the writers of You Are There attempted to utilize other means by which they could employ the politics of history. Rather than use allegory, they featured African Americans and women in non-normative roles and attempted to shed light upon historical narratives that challenged cold war strategy and consensus ideology. That said, Bernstein, Manoff, and Polonsky clearly felt limited in the extent to which they could pursue these narratives and otherwise construct more materialist interpretations of history.

In "The Emergence of Jazz," written by Abraham Polonsky, You Are There turns to a depiction of the closing of the Storyville district in New Orleans during the First World War. Aired November 5, 1954, the show centered around the debate over whether jazz was "mongrel music" or "the art of the twentieth century," and whether or not Storyville was a hive of moral depravity or the birthplace of a modern art form. Gathering these various opinions, CBS's newsmen interviewed the mayor of New Orleans and a representative of the Louisiana Federation of Women's Clubs. But the vast majority of screen time was taken up by African American jazz musicians. In a television series that each week was characterized by extremely verbose dialogue spoken rapid fire for twenty-five minutes, "The Emergence of Jazz" is striking for the amount of time reserved for the music itself, performed by African American jazz musicians. With Billy Taylor playing pianist Jelly Roll Morton, Zutty Singleton as Louis Mitchell, a drummer who helped bring jazz to France, and famed trumpet player Louis Armstrong, who closes the episode as King Oliver, the episode is one of the show's liveliest.

When the musicians are not playing, they deliver thoughtful monologues that argue against the notion that jazz is morally deprived or "mongrel music." Jazz “comes from hearing your mother's voice when you're on her knee and hearing there the voice of Africa and the drums and the people crying when they were dragged out of their homes and brought here to be slaves," Morton explains as he plays trills on the piano, "and it comes from working in the fields and talking up and singing against the hot sun and the pain and not letting on to the master what you were saying . . . and always the blues, always the slow drag." ${ }^{26}$ Authority, in "The Emergence of Jazz," is vested in the black musicians of Storyville, not the government officials or military men who are sent to close it down. At a time when very few blacks appeared on television and Amos 'n' Andy minstrel show stereotypes were the dominant portrayals of African Americans in popular culture, the episode provided a counternarrative that told of a rich African American culture and a recent past that was marked by repression by white Americans. ${ }^{27}$

The episode on jazz is an exception that proves the rule to You Are There's focus on populist or libertarian Euro-American ideas. For example, the Bernstein-penned episode "The Louisiana Purchase" draws heavily upon the debates about Federalists and anti-Federalists that drives historiography of the early Republic. Here, President Thomas Jefferson sends James Monroe to France in response to the threat of "backwoods" Mississippi planters who cannot utilize 


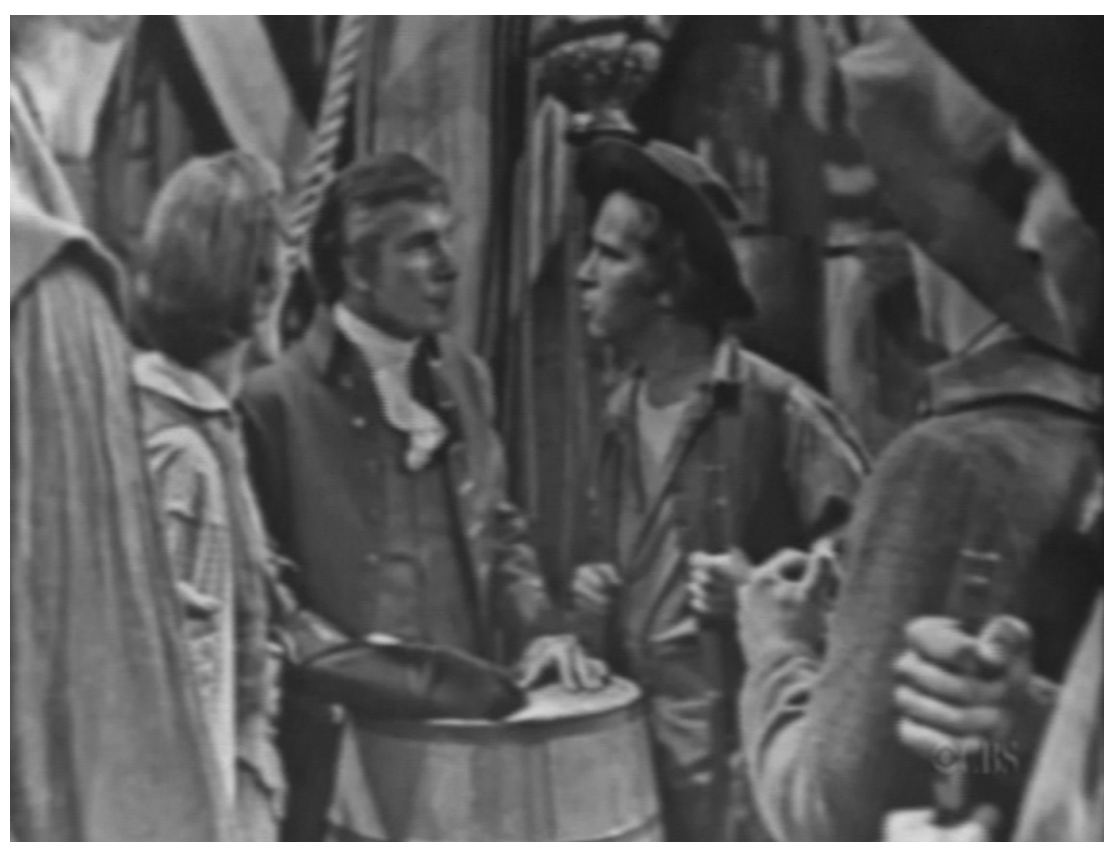

Figure 1: In You Are There's "Louisiana Purchase" episode, Mississippi Governor William C.C. Claiborne explains to Mississippi farmers that unlike the Federalists, Claiborne's political ally Thomas Jefferson is looking out for the farmers' best interests.

New Orleans as a trading port because the Spanish have sealed it off. As the episode opens, these planters are eager to go to war against France, the new owners of the Louisiana Territory. But a planter who proves his ruggedness by claiming he "can lick any man in Mississippi" and "swallow lightning" nevertheless offers a more level-headed approach; he says that Jefferson has proved "to be a real friend to . . . backwoods people" and suggests that they hold off on fighting. Along with the testimony of the governor of Mississippi, who suggests that Federalists want war for their own political ends, the "frontier men" of Mississippi decide to call off their march on New Orleans. Jefferson and Monroe, of course, succeed in solving the problem peacefully, obtaining the Louisiana Territory in the process.

"The Louisiana Purchase" undoubtedly ignores the issues of expansion and colonialism over native peoples that historians today are likely to address. But its celebration of Jeffersonian republicanism and western planters also falls in line with the mythological agrarian past that Progressive historians celebrated as an antecedent to the Populist movement. By portraying the backwoods planters of Mississippi as having agency in the events that led to the purchasing of the Louisiana Territory, the episode suggests that the "popular forces" had acted 
as catalysts in pushing the "vested interests" toward national progress. Such a dialectic was popular among Progressive historians such as Frederick Jackson Turner and Charles Beard. But by the 1950s, historian Richard Hofstadter had exposed these narratives as masking the Anglo-Saxon-centric discourses of "a belief in the rights of property [and] the philosophy of economic individualism" endemic to American populism. ${ }^{28}$

A similar invocation of Jefferson appears in Bernstein's script "The Vote That Made Jefferson President," which demonizes the Federalists and celebrates Jefferson's philosophical embrace of popular democracy and the freedom to believe in controversial ideas. But far from controversial, Jeffersonianism presented an alternative to more urban, cosmopolitan, or immigrant-centered discourses, according to Hofstadter. Its suspicion of concentrated state power appealed to both the anticommunists and left-liberals that had grown concerned with the threat of totalitarianism, but its paeans to individualism, its puritanism, and its ideology of self-reliance in production worked at cross-purposes to the goals of the pre-red scare Progressive left. According to Bernstein, Charles Russell had historians at New York University review the scripts of the show, but he did not go to Columbia University, where Hofstadter was tenured. ${ }^{29}$ Although Hofstadter was no political radical, one wonders what might have been had Russell gone uptown instead of the opposite direction.

Russell would not allow the writers to address certain topics. There is a noticeable lack of shows about the Great Depression or President Franklin Roosevelt, and the Spanish Civil War was undoubtedly off limits. Television writer Paddy Chayevsky submitted a script on the Triangle Shirtwaist Factory Fire, a landmark event in the American labor movement, but the episode was never made. ${ }^{30}$ And for a number of shows, Russell recruited other writers, ones that were not blacklisted, and these shows varied in the extent to which they reflected a left-liberal or critical approach to history.

Despite its limitations, in some ways You Are There did represent an alternative to the dominant consensus history of the fifties. Exemplifying the way this history manifested in popular culture is Cavalcade of America, a longrunning radio program that transitioned to a television show in October of 1952. The chemical company DuPont created Cavalcade of America in 1935 as a means by which the company could improve its public image through advertising. The architects of the show intended for it to be a triumphalist celebration of the American pioneering spirit and for its heroes to embody the same inventiveness and fortitude as did DuPont's chemists. Accordingly, Cavalcade of America, besides featuring frequent stories about the early settlers, the American Revolution, and World War II, also devoted whole episodes to men such as Elisha Otis, who invented the automatic safety device for elevators. In its six years on television, Cavalcade of America would earn seven awards from the Freedoms Foundation, a postwar organization that was founded to honor citizenship and patriotism, a record that serves to underscore the extent to which the show epitomized American exceptionalist history. ${ }^{31}$ 
Bernstein believes that the anti-McCarthyist nature of You Are There was allowed by CBS executives because the show was garnering high ratings. But people at the network were certainly aware of the nature of the show's content. At a bar with Russell, television journalist Edward R. Murrow congratulated him on the high quality of the show, and then asked Russell in a hushed voice, "How do you get away with it?"32

Ultimately, they didn't. It is unclear as to how long executive producer William Dozier knew about Russell using blacklisted writers on the show, but in 1955 he decided to move the show to Los Angeles and replace the production staff. Television production was increasingly moving from live broadcasting in New York to filming in Los Angeles, but Russell, Bernstein, and Polonsky were convinced that Dozier was partially motivated by his desire to rid the show of its subversive elements. The show lasted for another two seasons, but as Dozier adopted a more hands-on role in producing the show, it tended toward more celebratory narratives in history. ${ }^{33}$

The writers of You Are There undoubtedly would have liked to have taken the show further with its content. Although in newspaper interviews, memoirs, biographies, and oral histories, they express a profound sense of pride in their ability to wage a "guerrilla war" against anticommunism, a myriad of forces worked to guide their writing. The very atmosphere of the cold war and the realities of the blacklist put them on the defense. Frequent visits by FBI agents reminded Bernstein, Polonsky, and Manoff of their status as suspect in the eyes of their government and kept them on edge. ${ }^{34}$ And Russell, whose name, reputation, and career were on the line for aiding blacklistees, drew the line at certain treatments and topics, including the very events that were formative for the writers' political consciences, such as the Spanish Civil War, or the trials of the Scottsboro Boys or Sacco and Vanzetti.

If You Are There represented an alternative to the consensus history of scholars such as Daniel Boorstin and television programs such as Cavalcade of America, what then was the alternative that it was offering? It may have drawn upon the Progressive historians' tendency to lionize the backwoods farmers of the revolutionary era and the populist movement, but it elided their materialist emphasis on conflict in the American past. And it did not draw upon Richard Hofstadter's political-intellectual focus on the dangers of property-rights populism. In short, when Bernstein, Polonsky, and Manoff sought to write their more "political" shows, they mostly adopted civil libertarian rhetoric and failed to incorporate that of social justice.

\section{Swashbuckling at the Blacklist}

Just as Bernstein, Polonsky, and Manoff were being fired from You Are There, Hannah Weinstein emerged on the landscape of television production, offering new opportunities for blacklisted writers. Hannah Weinstein (née Dorner) had been a journalist for the New York Herald Tribune in the years of 
the Great Depression and after contributing to Fiorello La Guardia's 1937 campaign became a speechwriter for the New York mayor. Immediately after World War II, she served as Executive Director of the Committee for the Arts, Sciences and Professions (ASP), an organization that sponsored anti-red scare and pro-civil rights demonstrations and events. (In 1945, the ASP had incorporated Hollywood's largest Popular Front organization, the Hollywood Democratic Committee, to which countless liberal, socialist, and communist film industry workers belonged. $)^{35}$ Weinstein joined the ASP in supporting the 1948 Progressive Party presidential campaign of Henry Wallace, the ASP merging with a political action committee to form the Progressive Citizens of America. After Wallace's campaign drowned in the rising tide of anticommunism, she left for Europe, disillusioned with the political climate in the United States. Weinstein decided to start her own television studio in England and serve as its producer. She would hire almost exclusively blacklisted writers. ${ }^{36}$

Weinstein's first television show, Colonel March of Scotland Yard, ran on American television in syndication from 1954 to 1956, and it employed Bernstein and Polonsky for a brief time. ${ }^{37}$ But Weinstein achieved far greater success with The Adventures of Robin Hood, the first production created under her new studio, Sapphire Films. The popular television show would run original episodes in the United States and Great Britain, from 1955 to 1958, for a total of 143 episodes, and would continue to be shown throughout the early sixties. ${ }^{38}$

Weinstein and her story editor, Arthur Ruben, carefully implemented a system by which blacklisted writers, who remained in the United States, could contribute to the British show. They started by employing Ring Lardner, Jr., and Ian McLellan Hunter. Lardner and Hunter had become close friends after meeting in 1935; both were reporters for the Daily Mirror in New York City. Lardner had been called before the House Committee on Un-American Activities (HUAC) in 1947 as one of the "Hollywood Ten," his testimony featuring the most memorable line of the hearings. When asked to answer the question of whether or not he was a communist, Lardner retorted: "I could answer it, but if I did, I would hate myself in the morning." Lardner went to prison for contempt of Congress, as did the other nine "unfriendly" witnesses. Hunter, meanwhile, earned an Academy Award for Roman Holiday (1953), a screenplay that another blacklisted writer, Dalton Trumbo, had contributed to but did not receive screen credit. Hunter's guilt over the incident was assuaged when he too became blacklisted soon later. ${ }^{39}$

Hunter and Lardner worked collectively on just about every script of the first season of The Adventures of Robin Hood, after which time other writers were brought in as well. Over the years, the show employed at least a dozen blacklistees. ${ }^{40}$ Lardner and Hunter would continue to work for Weinstein in writing other shows, including The Buccaneers (1956-57) and the less popular Sword of Freedom (1958), and just as with Robin Hood, on every one of Weinstein's shows they were later joined by a widening, rotating cast of other blacklisted writers. ${ }^{41}$ Ruben and Weinstein employed a system whereby each writer 
was assigned multiple pseudonyms, so that the television executives at CBS or ITV would not become too interested in the work of any single writer. Lardner recalls the careful manner in which they went about getting paid; paychecks were made out to pen names that the writers had registered with Social Security, and the writers deposited their pay into savings accounts, but never checking accounts, because to open one required the depositor to provide identification. ${ }^{42}$ Unable to obtain passports, Hunter and Lardner stayed in New York and mailed their scripts to Weinstein and Ruben in England. ${ }^{43}$

Like Bernstein, Manoff, and Polonsky, the writers of The Adventures of Robin Hood understood clandestine television writing as a means to strike back against the ideology of the red scare. "There were many social issues you could deal with," remembered Lardner, "by going back to the twelfth century and having a bandit as your hero." He and Hunter "found all sorts of variations," he says, on approaches to contemporary topics. ${ }^{44}$

Weinstein could have done worse than to select the legend of Robin Hood as a means to challenge the cultural climate of the cold war and allegorize the contemporary geopolitical conflicts of the period. Robin Hood, according to legend well known in both England and the United States, was an outlaw with a keen sense of social justice, who robbed from the rich and gave to the poor. His antagonistic attitude toward the authoritarian Prince John and the Sheriff of Nottingham had the potential to reflect midcentury antifascist sentiments. And his empathy toward the poorest of England's inhabitants could reflect socialist and Popular Front positions on wealth distribution and the understanding, articulated by Franklin Roosevelt, that all citizens of the world deserved to be "free from want."

Particularly in England, Robin Hood had served as a kind of popular agrarian myth. According to the story, the Saxon people, who were yeoman farmers, had become serfs under the feudalistic rule of the Norman invaders. Although its roots predate the birth of liberalism, the Saxon myth bears a great resemblance to the Jeffersonian utopia that is so often conjured as the wellspring of democracy in a mythical American past. So The Adventures of Robin Hood drew from a symbolic language common to populist mythology in both the United States and England. Weinstein's The Adventures of Robin Hood took the time in almost every episode to invoke the language of "Normans" and "Saxons."

The British recall the feudalism of the period as the "Norman yoke," but we might instead say that Prince John's Norman regime put the inhabitants of Weinstein's England, quite literally, on the "road to serfdom." At the end of World War II, free market economist F. A. Hayek's The Road to Serfdom challenged the centrally planned economies of the Soviet Union and the wartime United States by tying such regimes to the threat of a new totalitarian economic feudalism. Hayek and others, in the years following the war, shifted political discourse away from antifascism, which saw autocrats as evidence of the failures of capitalism and as obstacles to class consciousness, toward one that un- 
derstood autocrats as obstacles to free market productivity. ${ }^{45}$ The Adventures of Robin Hood was caught in the middle of this shift. In the cultural context of the late fifties, the Normans could stand in for antiliberal totalitarians much better than they could represent moneyed trusts or monopolistic corporations.

In several episodes, conflict centers around the lower class members of Nottingham being denied political rights rather than economic rights. They are impressed into a malevolent Norman aristocrat's army in one episode. In another episode, "Children of the Greenwood," a boy and a girl are made into serfs after their father is framed for murder. "No matter how poor we are," the father counsels his son at the start of the episode, "you are a free man." That his family's land is taken away subsequent to his arrest matters less than the loss of autonomy that ensues as a result of Norman tyranny. The television show undoubtedly cultivates sympathy on behalf of its economically unprivileged protagonists. But it finds its solutions in a kind of populism that celebrates a mythic individualistic ideal. Rooted in England's championing of the Saxon yeoman, but also in the powerful Jeffersonian agrarian myth that has guided American political thought since the birth of the republic, this populist rhetoric in the United States traditionally pits producers - exemplified by the small farmer or petit bourgeois - against both concentrated capital and the landless, idle, or unskilled poor. Whereas populism in the 1930s had been imbued with the antifascist, social democratic politics of the Popular Front, in the postwar

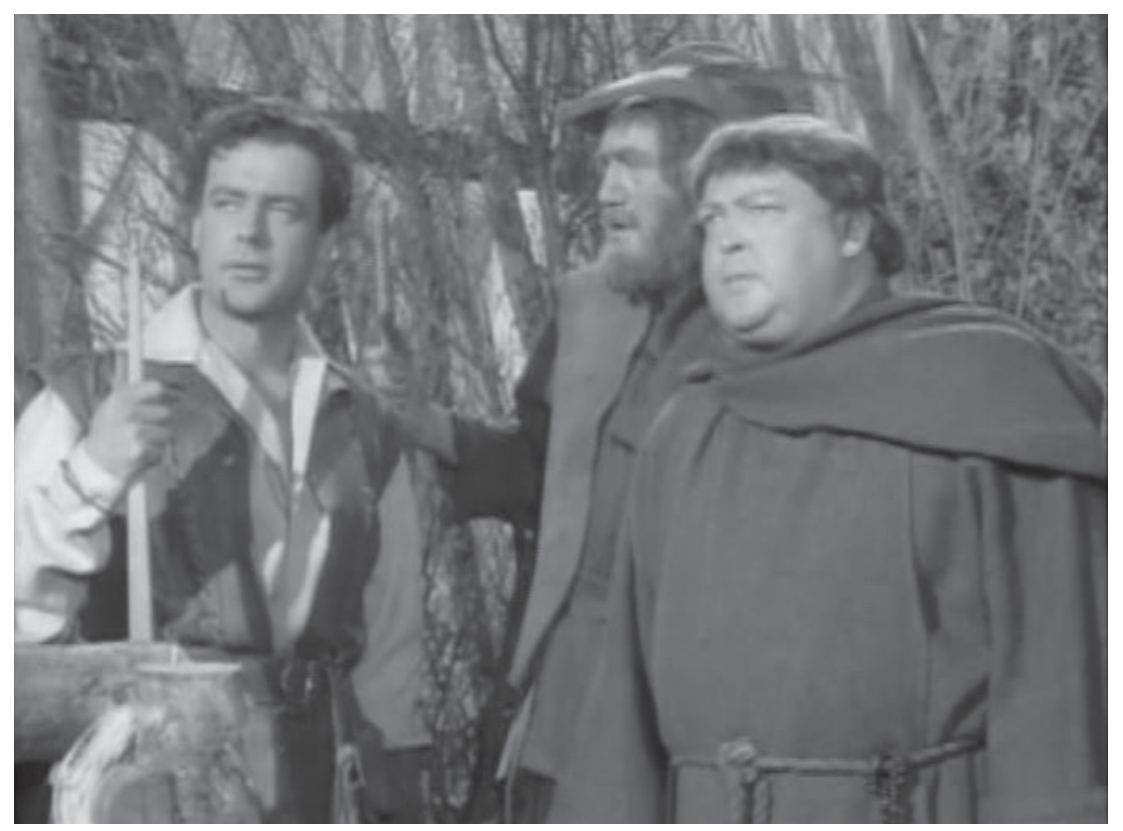

Figure 2: Richard Greene as Robin Hood, alongside Little John and Friar Tuck, in The Adventures of Robin Hood. 
period, populism in the United States increasingly became a vehicle for a more libertarian kind of politics.

As was the case with You Are There, the writers of The Adventures of Robin Hood often took the opportunity to speak directly to the injustices of the Hollywood blacklist. In an episode titled "The Vandals," the sheriff interrogates a village ironsmith in an attempt to make the man confess that he has made arrow tips for Robin Hood. "I know you are a decent citizen now," the Sheriff goads him, evoking the language of HUAC inquisitors that sought to guilt former radicals into naming the names of communists and fellow travelers. The ironsmith reveals Robin Hood as the benefactor of his arrow-making skills, and in doing so implicates Robin in a crime. But the ironsmith is ashamed of his actions and eventually finds Robin in the forest and warns him. In another Lardner and Hunter episode, "Blackmail," a man stumbles upon Maid Marian and Robin talking in the forest and threatens to inform the Sheriff of Nottingham of Marian's fellow-traveler-like association with the outlaw. Robin outwits both the man and the Sheriff, and the confused Sheriff ends up killing the man. ${ }^{46}$

Another episode employs the witchcraft allegorical strategy that had become quite popular by the middle of the fifties. In "The Ordeal," penned by Lardner and Hunter, the Sheriff of Nottingham hatches a plot to turn villagers against Robin's band of merry men by framing one of them for murder. ${ }^{47}$ The sheriff sows rumors among the villagers, precipitating a mob mentality that quickly grows out of control. The zealous villagers plant evidence to affirm their suspicions that the outlaw Edgar has committed the crime and force Edgar to face a trial in which he will have to grasp an iron rod that has been heated in a fire. If Edgar's hand blisters, it is evidence of his guilt. By investigating in the village, Robin and Friar Tuck are able to reveal to the townspeople the inconsistencies and untruths behind their accusations, and the true criminal is revealed. The episode condemns the irrationality of mobs and also the show trials of totalitarian states such as the Soviet Union as well as the dramatic political theater of McCarthyism.

Shortly after "The Ordeal" aired in the show's first season, The Adventures of Robin Hood returned even more directly to the witchcraft theme. In "The Alchemist," a poor village woman is accused of being a witch because she has mysteriously come into possession of a gold plate, which she is trying to sell so that she can afford to pay the Sheriff's onerous taxes. The plate had been smuggled into the village by her son, one of Robin's merry men. Were she to explain this to the villagers, she would endanger him. At night, one villager sees the woman standing in front of a tree, in such a position that it appears as though she is adorned with horns, and rumors begin to spread.

An accusing villager brings the woman's plate to the sheriff, who quickly determines that the plate is not the product of a witch's alchemy. He recognizes the seal on the plate as one that belongs to a Norman aristocrat whose goods had been recently pillaged by Robin's men. But the sheriff determines to use the people's hysteria as a means to draw Robin into a trap. With the accused woman 
on trial, he has no doubts that her son will attempt a rescue. The sheriff concocts a plan in which the villager will heighten the town's hysteria by poisoning cattle and spreading rumors. In the end, Robin and his men expose the plan and save the woman before she is burned at the stake. But false accusations of witchcraft would reemerge in at least one more subsequent episode. ${ }^{48}$

Increasingly, The Adventures of Robin Hood focused less on the ways in which townspeople were burdened by the Sheriff's onerous taxes, and more on the posturing and politicking of nobles who were either loyal to the absent King Richard or looking to capitalize on the reign of the usurping Prince John. The heroes of the show were quite often members of the estate-holding class. The good nobles tended to be more fair to the peasants who worked their land than their evil Norman counterparts, this the show made apparent, but their own woes were far more central to the show's storylines than were those of their serfs and servants. They were tremendously wealthy in property, but burdened by the Norman tax scheme. They also tended to be more sympathetic to Robin and his band of outlaws, but not because they believed in wealth redistribution, but rather because they knew Robin to be loyal to King Richard and were loyal to him as well. Upon meeting Robin, these nobles tended to invoke his history of having served alongside Richard in the Crusades instead of his history of being an altruistic outlaw.

Particularly as the show entered its second year, the storylines elaborated on the tensions between the forces of John and those of Richard. Several of these episodes feature a character named Sir Richard of the Lea, a sympathetic estate holder who is loyal to King Richard. One Hunter and Lardner episode, "The Deserted Castle," finds the Queen Mother Eleanor hiding in secret, where she helps Robin thwart Prince John's plan to ally with France against those loyal to her son. In a couple of episodes also penned by Hunter and Lardner, "Richard the Lion-Heart" and "Secret Mission," a mysterious pilgrim named Peregrinus aids Robin in combatting Prince John's forces. Peregrinus, it turns out, is King Richard in disguise, who for reasons that go unexplained has returned to England but is reluctant to reveal this to his subjects. In another episode, "The Traitor," some nobles have raised money to pay King Richard's ransom - they do not know that Richard is free and has secretly returned - but one of them is secretly conspiring to intercept the money and bring it to Prince John. The question of the distribution of wealth is seldom about the rich and the poor in these episodes, but is instead about those loyal to King Richard versus those loyal to Prince John.

\section{"Primitive Rebels" and Liberal Governance}

Venerable historians Paul Buhle and Dave Wagner have celebrated the ability of blacklisted writers to challenge "McCarthyism" by writing for films and television in various clandestine ways. They champion The Adventures of Robin Hood for portraying the Normans as "fascistic invaders" and their aristo- 
cratic appeasers as collaborators. ${ }^{49}$ Weinstein's Robin Hood, Buhle and Wagner write, represented a "primitive rebel," an archetype that they note "resisted the invasion of capitalism while appealing for a return to the social institutions of some earlier, happier age. ${ }^{50}$

They borrow the term "primitive rebel" from British historian Eric Hobsbawm. But in the context of The Adventures of Robin Hood, Hobsbawm's concept of the "primitive rebel" deserves more attention, for Hobsbawm is more critical of the phenomenon than Buhle and Wagner suggest in their passing reference. In Primitive Rebels, Hobsbawm notes how the social banditry evoked in the stories of Robin Hood is always placed within a rural setting rather than an urban one, and that the bandit's presence necessitates a "pre-political" context. In the context of Hobsbawm's Marxist analysis of history, social bandits are ineffective because they reference a stage before that of proletarianization, and they do little to effect that stage in the stories about them. "Bandit-heroes," he writes, "are not expected to make a world of equality." Their form of protest, he contends, is "modest and unrevolutionary." 51

The story of Robin Hood is undoubtedly backward looking and "primitive;" the character derives from and conjures a mythical agrarian past that fails to offer solutions to the social questions of the twentieth century. The serfs of Robin Hood's times had bigger concerns than the alienation of their labor. Lacking basic political rights in a precapitalist, preliberal society, their fundamental interests were in resisting Norman rule, which English mythology suggests supplanted a more idyllic, egalitarian Saxon society.

But we can also understand that myth itself as functioning as a kind of modern technology of governance, well suited to postwar conceptions and projects of liberalism. In this way, Robin Hood and other roguish rebels aren't simply anachronistic, but they appear as suitable vehicles for libertarian critiques against modern state intrusion. Simultaneously, because they tell stories about a preindustrial age, they are ill-equipped to critique the extra-state governance of advanced liberal capitalism. Invoking Anglo-Saxon and Jeffersonian mythology, they reinscribe, to use historian James Livingston's parlance, a discourse of "modern subjectivity" in which "romantic individualism" is central. ${ }^{52}$ The story of Robin Hood isn't simply "prepolitical," it's well suited as an expression of certain ideas about markets and governance that are central to neoliberalism.

The romantic individualism of anglophone mythology, we might note, was decidedly not a staple of Progressive rhetoric during the immediate postwar years in the United States, when Henry Wallace was reflecting and shaping the rhetoric of Weinstein and other members of the Popular Front. Wallace himself had been careful to distinguish between political freedom - what he termed "bill-of-rights democracy," which he said that unchecked, leads to "rugged individualism, exploitation, impractical emphasis on states" rights, and even to anarchy"-and the "new democracy," economic freedom, which "abhors imperialism" and seeks "economic, educational, ethnic, and gender democracy." 53 In contrast to his "new democracy," Wallace rejected Winston Churchill's stri- 
dent anticommunism of the forties, which he derided as "Anglo-Saxon Ueberalles." 54 Just like Hofstadter, Wallace had located a dangerous counter-Progressive current in the anglophone tradition from which The Adventures of Robin Hood drew. In his criticism of Churchill's proposed Anglo-American alliance, he echoed sentiments of the CPUSA and the Popular Front. ${ }^{55}$ But these echoes failed to reverberate through The Adventures of Robin Hood.

\section{The Unfulfilled Promise of The Buccaneers}

Hannah Weinstein sought to capitalize on the early success of The Adventures of Robin Hood by producing several other shows in the "swashbuckling" genre. After recruiting other blacklisted writers, she pulled Lardner and Hunter from Robin Hood and had them work on The Adventures of Sir Lancelot (195657) and The Buccaneers (1956-57). Later, Weinstein produced similar shows using similar methods, Ivanhoe (1958-59) and Sword of Freedom (1958). ${ }^{56}$

One of the more popular shows, The Buccaneers, illustrates the difficulties that blacklistees had in trying to subvert the anticommunist climate of the early cold war. The show's action centered on the eighteenth-century British colonial port of Nassau in the Bahamas and featured a privateer named Dan Tempest, a reformed pirate now in the service of the crown as a privateer and hired guardian of the island of New Providence. Tempest, like Robin Hood, is a roguish individual who tends to buck authority, although he ultimately bears allegiance to the orderly forces of good, which in this case is the British colonial government. His enemies are the Spanish and pirates like Blackbeard and, to a lesser extent, bureaucrats and colonial governors with whom Tempest might bump heads.

The first few episodes of the show, which began airing in September 1956, narrate Tempest's conversion from pirate to privateer. ${ }^{57}$ The governor of the Bahamas issues amnesty to all pirates that might join the British. The governor himself, formerly a privateer, rejects the classist dismissal of pirates that is prevalent among his peers, understanding them to have been mistreated by an overly imperious British administration. By displaying an even hand, the governor seeks to usher in a period of consensus and cooperation that will serve the colonialist aims of the mother country.

Blackbeard rejects the deal, but Tempest accepts it. Tempest subsequently reckons with the attitudes of the less than progressive planter Van Brugh, who is wary of rugged, low men like Tempest, and with his former friends who see him as an emasculated shell of his pirate self. His girlfriend Lolita even leaves him. But Tempest soon proves himself to be both a dutiful British subject and a strong, individualistic leader. He aids the British colonial government of New Providence in thwarting the Spanish, repelling pirates, and in occasionally rebalancing the scales of justice when the governor or his lieutenant enact an unjust policy.

An early show about slavery attempted to tackle the matter of race. In "Slave Ship," the seventh episode of The Buccaneers, three indentured servants 
who had been working a plantation on New Providence, under the unsympathetic landowner Van Brugh, escape from the island in a rowboat. At sea, they board a British vessel and, assuming the role of pirates, manage to overtake the crew of the ship and send them away in the ship's longboats. The three men assume they are alone on the vessel, until they find that there are slaves from Africa, bound in irons, down in the cargo hold.

One of the former indentured servants is black, and he communicates with the slaves in a shared language. The reluctant pirates agree to free the slaves, provided that they will work on the ship as its crew. One of the pirates has assumed command of the ship, with the others' consent, and he declares that on his ship, "all men are free, and all men are equal." They name the ship "The Liberty," and the slaves break into song in their native tongue.

Meanwhile, the ship's exiled crew lands on New Providence and informs Tempest and the other figureheads of the island that their ship has been taken by pirates. The slaves, it turns out, were to be delivered to Van Brugh, and he tasks Tempest with getting them back. Tempest sets out for the Liberty, and his men retake the ship, defeating the three rookie pirates in swordplay but ultimately leaving them unharmed.

Tempest questions the assumed leader of the three and is sympathetic to their situation as runaway indentured servants. He takes the money that the leader of the pirates had stolen from the ship's captain and then lets the three escape in a rowboat, pointing them toward Jamaica, where Tempest tells them they will be safe. He then sets out to deliver the slaves to Van Brugh.

Finally, Tempest reaches New Providence, arriving to applause. Upon greeting Van Brugh, Tempest tells him that he wants to buy the slaves. In a clever act, Tempest uses the money that was stolen from the ship's captain - to whom Tempest had denied that he had recovered his stolen purse - to outbid Van Brugh in an impromptu slave auction. The slaves, Tempest declares, are free, and he asks Lieutenant Governor Beamish to set them to work as settlers on the island. "The Slave Ship," most likely written by Waldo Salt, succeeds in portraying black characters when few were shown on the small screen and in its depiction of Africans in bondage in the new world, perhaps a first for the nascent medium. ${ }^{58}$ But it falls short of humanizing its black characters, in investing them with any authority, or in suggesting in any way that the crimes of the past were left to be reckoned with in the present.

After the show began airing, Weinstein became concerned about its ratings. Subsequently, the show's story editor, Peggy Phillips, led a change in the direction of the show, in which Tempest would no longer be bound to working for the governor of New Providence, but instead would become more of a "freebooter," which would enable him and his crew to have more exciting adventures. The show's new alignment, as Phillips expressed it, would also allow the story writers to engage with the history of the colonies of what would become the United States. No longer would the Spanish be the primary villains. Instead, Phillips imagined that Tempest could "[aid] the cause of the American people 
against repressive rule, [and help] the struggling young colonies in their stand for independence and rebellion against the oligarchy." ${ }^{59}$

Waldo Salt - Sapphire's most trusted writer besides Lardner and Hunterhoped that the new format would allow the writers to explore further the issue of slavery, and he set about researching the plantations of South Carolina. ${ }^{60} \mathrm{He}$ developed copious notes on a storyline that would paint the slave economy of the colonies as the product of the South Sea Company, a monopolistic corporation. Upon encountering this capitalist monstrosity, Tempest would become a kind of sea-faring Robin Hood. ${ }^{61}$ In Salt's imaginings, Tempest "preys on fat merchant ships" and serves on the side of "fishermen, small farmers, bond servants, slaves, [and] artisans." Salt even created a new backstory for Tempest, in which his "hatred of injustice and slavery" is rooted in his being kidnapped and enslaved himself as a child. ${ }^{62}$

Ultimately, Salt and his colleagues largely failed to incorporate any kind of subversive material into the new version of The Buccaneers. They came close with a couple of episodes, however. In the second episode of the new storyline, "Dan Tempest Holds an Auction," Tempest and his crew arrive in Charleston, South Carolina. Tempest learns from a colonist named Paula, a tenant on a tobacco farm, that the governor of the South Carolina Trading Company is cheating his tenants by buying their crops at untenably low prices and by forbidding them to sell their goods on the "open market." Because the tenant farmers work for the company, they can do business only with it and are forbidden from taking their goods "upriver."

Later in the episode, Tempest calls a meeting of local planters, suggesting that they need to stand up together to the colony's governor. He hatches a plan by which he will bring the planters' tobacco onto his ship and sell it in Boston for a fair price. At the conclusion of the episode, as Tempest is preparing to leave port, the governor suddenly issues a "port tax" that equals half of the value of Tempest's cargo. Tempest contests the tax as illegitimate and proceeds to clash swords with the governor. After the governor concedes defeat and allows Tempest to leave, Paula declares to Tempest, "you've taught us how to stand and fight together."

It is unclear exactly who wrote the episode, penned under the name Alan Moreland. But it clearly seeks to impart a left-liberal message. The governor has turned South Carolina into a company town of sorts, and the planters learn that by taking collective action, they can subvert his power. But by the end of the episode, the show illustrates some of the same populist tendencies as did The Adventures of Robin Hood. The obstacle to social justice is onerous taxation. Furthermore, we might read the farmer's search for "open markets" as less of a critique of industrial capitalism than one of eighteenth-century mercantilism. Another read might also see the show's critiques of price controls as attacks on the kinds of economic planning favored by Franklin Roosevelt and Henry Wallace. Ultimately, it is the dual nature of the governor as both political and commercial ruler that suggests a libertarian populist read-one that finds 
suspicion of both concentrated capital and big government—above other possibilities.

Another episode that followed soon afterwards further reveals the limits by which The Buccaneers could challenge liberal consensus discourse. In "Mistress Higgin's Treasure," Tempest and the crew of his ship, The Sultana, are bringing farming supplies to colonists in Virginia. According to a diary entry that he narrates in the beginning of the episode, he is delivering the supplies stealthily because the taxes on the products haven't been paid. The farmers, he writes, are starving because of the taxation policies of the crown.

Tempest is quickly sidelined in a plot that involves an entrepreneurial school mistress who is searching for buried treasure. And he ends up having to fight not plantation owners or British tax officials, but pirates who have stolen the farmers' goods and who are also seeking the treasure. Curiously, one of the farmers speaks of growing indigo, a staple of the large, slave-dependent plantations of the American colonies. The episode, as did The Adventures of Robin Hood, takes great care to lionize the independent, yeoman farmer, but says nothing about the capitalistic structure that in reality implicated indigo production with these plantations on which slaves labored. ${ }^{63}$ Even the tenant farmers of the aforementioned episode are gone from the story; independent landowners replace wage laborers.

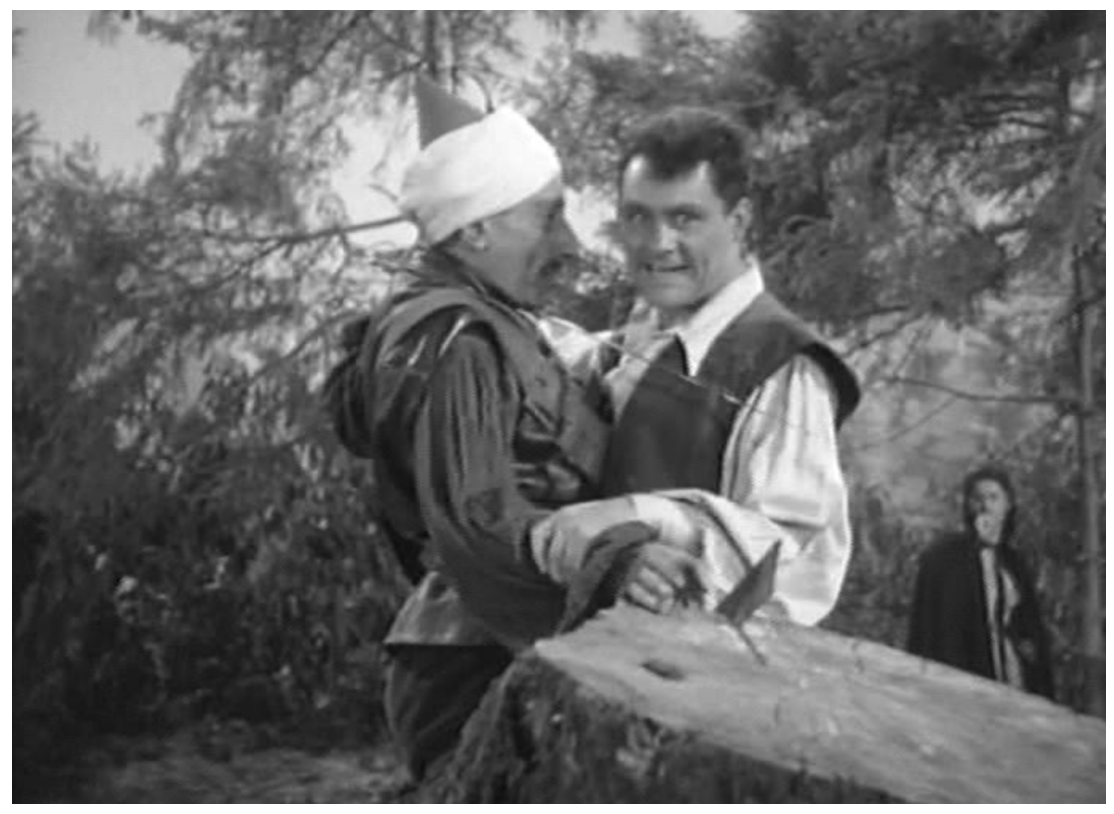

Figure 3: Robert Shaw (center) as The Buccaneer's Dan Tempest, doing battle with "The Turk," the South Carolina colonial governor's sword-for-hire, in an episode title "The Decoy." 
Other episodes that followed Tempest's departure from New Providence strengthened the notion that the enemies of industrious, plain Americans were members of an imperious political class that sought to tax the producing classes. In one episode, an indentured servant laments not his economic position, but that the lord of the island on which he works won't let him school his children. All the man wants is that his owners "stay within the law," he tells Tempest, and he desires to work within the system to earn his freedom. His eventual goal, he continues, is to own his own land, which he can work, in his words, at "profit or loss." He seeks not economic parity or security, but rather political liberty. And he seeks not structural change, but rather he places faith in the primacy of the legal contract to which he is bound as a rational individual actor.

The new stretch of episodes lasted for ten episodes, until The Buccaneers was canceled, although not all of the shows featured tyrannical British colonial governors. The crew of the Sultana was still encountering malevolent pirates during their time away from port. Some of these latter episodes have the royal governors working with unsavory pirates to steal treasure or thwart Tempest's goals, perhaps indicating in a kind of shorthand that the British officials were men of unscrupulous means.

The show's turn away from New Providence and toward the colonies that would become the United States did not result in much of a critique of capitalism, nor did it result in any kind of critique of systemic racism. Instead, it offered audiences a narrative of American history that elided class conflict and celebrated what was understood, on both sides of the pond, as virtuous characteristics of Anglo-Saxon tradition: the contributions of yeoman producers and the importance of liberal governance instead of tyrannical rule. We can only speculate as to whether or not the project that Salt and his fellow writers failed to accomplish would have fared any better in the days before the dissolution of the Popular Front. But The Buccaneers was clearly shaped by the left's renascent antistatist lexicon that had emerged in the wake of the red scare and subsequent events such as the Korean War.

\section{The Limits of "Resistance" in Blacklist Era Television}

It might be that the rhetoric of Weinstein's shows was entirely lost on the audience. But The Buccaneers still contributed to a discourse that worked at cross-purposes to the Popular Front - era vision of a more inclusive, multicultural, and egalitarian America. Just like the episodes of You Are There that addressed the American past, Weinstein's show presented a history of the United States in which the promise of democracy is realized through independent and entrepreneurial white Anglo-Saxon Protestants. As Alan Nadel illustrates in Television in Black-and-White America, the show was not alone in reinforcing normative ideas around whiteness. He argues that television westerns in the fifties and sixties, like Disney's Davy Crockett, were particularly instrumental in the dissemination of images that linked Americanness, whiteness, and "Anglo- 
Saxon" libertarian values. ${ }^{64}$ The absence of black characters in 1950 s television served to normalize America as a white nation, and the contexts in which characters were placed - in the historical West, in moments of national founding, and in the cases of situational comedies, in nuclear families - served to reify certain constructions of normative Americanness that were coded white.

In contrast, the writings of Popular Front - era leftists show that left-liberal intellectuals and artists were concerned with narrow conceptions of Americanness proliferating popular discourse.$^{65}$ These concerns seem to have fallen out of public discussion with the dissolution of the PCA and the development of the red scare. Weinstein's writers could only reach back to the discourse of the Popular Front era in terms of their faith in a populist brand of politics. But without the social democratic context and the analytical lens of the earlier movement, that which linked race and class, and that which sought civil rights over individual liberties, their messages contributed to a libertarian definition of Americanness that excluded the possibility of structural solutions to economic and racial inequality by championing roguish individualism and entrepreneurial labor and by writing American history as the story of white people.

Whether or not blacklistees convinced television viewers of the evils of political witch hunts is not clear. They may have made the political strategies of "McCarthyism," in all of its incarnations, unpalatable to Americans, and given them an allegory-rich language of civil libertarianism with which they might voice their disdain. And this is no small thing. As Thomas Doherty suggests in Cold War, Cool Medium, the anticommunist programs of men inside and outside of state structures that sought to neutralize the expression of ideas that were contrary to their own interests were, in the long run, stunted by the civil libertarian efforts of television industry workers. ${ }^{66}$

But blacklisted writers in television also contributed to the proliferation of a left-liberal discourse that worked, as the century progressed, at cross-purposes with the social democratic and civil rights-based spirit of the Popular Front. This has been overlooked by some scholars of the blacklist, who have erred in assuming that all liberal or leftist discourses are symbiotic with one another, and that such systems of ideas are static, and in assuming that resistance or counterconduct is defined by its agent rather than its cultural context. Although Bernstein, Manoff, Polonsky, Lardner, Hunter, and others may have succeeded in undermining the hysteria of McCarthyism, they were not able to revive the kinds of discussions that were central to the Popular Front, such as those surrounding the Fair Employment Practices Commission and other movements for racial and economic justice.

How then do we understand the meaning of "resistance" in the context of twentieth century American liberalism? As sociologist Nikolas Rose suggests in Powers of Freedom, discourses of freedom can operate both as "formula[s] of resistance" and as "formula[s] of power." ${ }^{\text {"67 }}$ The traditional notion of resistance, that which is understood to be constituted "from below" and in opposition to a single, focused source of power, Rose argues, is "too simple and 
flattening," for it works as "merely the obverse of a one-dimensional notion of power as domination." To look beyond, he suggests, is to "diagnose the historically shaped limits" of our political imaginations. ${ }^{68}$ Here, I have suggested that the imaginations of the liberal-left were guided and circumscribed by their own discourses of resistance. Writers leaned heavily on the kind of Jeffersonianism that lent itself not only to antitotalitarianism, but also to enshrining American individualism. In the case of You Are There and in the later episodes of The Buccaneers, they often did so in explicit historical terms. And in The Adventures of Robin Hood, they invoked a similar Anglophone historical mythology that romanticized a preindustrial, agrarian past. In doing so, blacklist television aided a much larger discursive process in which political liberties went from being a means to social justice to being an end in itself.

\section{Notes}

1. Thomas Doherty, Cold War, Cool Medium: Television, McCarthyism, and American Culture (New York: Columbia University Press, 2003), 7-8.

2. Ibid., 3.

3 .Andrew Falk, Upstaging the Cold War: American Dissent and Cultural Diplomacy, 19401960 (Amherst: University of Massachusetts Press, 2010), 6, 10.

4. By "civil libertarianism," I mean a rhetoric or platform that stresses the importance of and pushes for the safeguarding of civil liberties. Civil liberties are different from civil rights in that they tend to be defined as limitations on the state, rather than as programs of the state. Freedom of speech, for example, is a civil liberty, as it is understood as limiting the government's ability to punish or prevent an individual from expressing oneself. The right to a minimum wage or certain standard of living, on the other hand, would be a civil right, because its realization requires action on the part of the state. Civil rights and civil liberties are by no means mutually exclusive, and the invocation of one may serve as a means to an end of securing the other. For example, the American Civil Liberties Union was founded to protect the political expression of those who were seeking labor rights, social justice, and racial equality; they invoked civil liberties as a means to fight for civil rights. But the fact that "civil libertarianism" bears a close resemblance to "libertarianism," an ideology that entirely eschews civil rights, has some significance that I hope is reflected in my use of the former term.

I use the very broad term "left-liberal" throughout the article to describe those who shared thoughts characteristic of or descending from the politics of the Popular Front coalition of the thirties and forties. Doug Rossinow argues for the appropriateness of the term in discussing the political culture of the first half of the twentieth century. We should heed his warning, though, particularly in thinking about "left" and "liberal" political currents of the last few decades, that the term's individual constituents are not interchangeable. Doug Rossinow, "Partners for Progress? Liberals and Radicals in the Long Twentieth Century," in Making Sense of American Liberalism, ed. Jonathan Bell and Timothy Stanley (Urbana, IL: University of Chicago Press, 2012), 17-37.

5. Congressional Theatre by Brenda Murphy is a good example of the focus on criticism of demagoguery and the cold war state during the blacklist period: Congressional Theatre: Dramatizing McCarthyism on Stage, Film, and Television (New York: Cambridge University Press, 1999).

6. My language here reflects the influence of governmentality studies. See Mitchell Dean, Governmentality: Power and Rule in Modern Society (Thousand Oaks, CA: Sage Publications, 1999).

7. Jeff Kisseloff, ed., The Box: An Oral History of Television, 1920-1961 (New York, Viking, 1995), 421; Walter Bernstein, Inside Out: A Memoir of the Blacklist (New York: Alfred A. Knopf, 1996), 233; Abraham Polonsky, "Archive of American Television Interview," Archive of American Television, July 6, 1999; Walter Bernstein, "Archive of American Television Interview," Archive of American Television, July 21, 2004.

8. Bernstein, Inside Out, 125-31.

9. Ibid., 208.

10. Polonsky, "Archive of American Television Interview"; Paul Buhle and Dave Wagner, $A$ Very Dangerous Citizen: Abraham Lincoln Polonsky and the Hollywood Left (Berkeley: University of California Press, 2001).

11. Bernstein, "Archive of American Television Interview."

12. Buhle and Wagner, A Very Dangerous Citizen, 11. 
13. Bernstein, Inside Out, 208.

14. Ibid., 22-23.

15. Ibid., 154-57; Bernstein, "Archive of American Television Interview."

16. Bernstein, "Archive of American Television Interview"; Polonsky, "Archive of American Television Interview."

17. Abraham Polonsky, You Are There Teleplays: The Critical Edition, ed. John Schultheiss (Northridge: Center for Telecommunication Studies, California State University, 1997), 315-16.

18. Bernstein, Inside Out, 216-17; Polonsky, You Are There Teleplays, 11.

19. Bernstein, Inside Out, 216-18.

20. Ibid., 216-17; Polonsky, You Are There Teleplays, 325.

21. Bernstein, Inside Out, 222.

22. Polonsky, "Archive of American Television Interview"; Bernstein, "Archive of American Television Interview"; Bernstein, Inside Out, 220-22.

23. Airdates are culled from several sources: Polonsky, You Are There Teleplays, 318-21; Variety Television Reviews, 1923-1988 (New York: Garland, 1989); "You Are There: Episode Listings," CBS Interactive: tv.com, 2009, http://www.tv.com/you-are-there/show/5397/episode_listings.html, accessed March 26, 2009.

24. J. P. Shanley, 'New Miller Play Opening Tonight: 'The Crucible,' Tale of Salem Trials, at the Martin Beck-Kennedy Hampden Co-Star," New York Times, January 22, 1953, 20; Brooks Atkinson, "The Crucible': Arthur Miller's Dramatization of the Salem Witch Trial in 1692," New York Times, February 1, 1953, X1. 1988.

25. "Tele Follow-Up Comment," Variety, April 1, 1953, in Variety Television Reviews, 1923-

26. Polonsky, You Are There Teleplays, 252.

27. Amos ' $n$ 'Andy had in fact been dropped by CBS the year prior because the network could not find a sponsor for a show that featured an all-black cast. James Baugham cites the protests of both sponsors and Southern network affiliates as reasons behind an almost complete absence of African Americans on television in the fifties. George Lipsitz, Time Passages: Collective Memory and American Popular Culture (Minneapolis: University of Minnesota Press, 1990), 48, 63-65; James Baughman, Same Time, Same Station: Creating American Television, 1948-1961 (Baltimore: Johns Hopkins University Press, 2007), 209.

28. Richard Hofstadter, The American Political Tradition and the Men Who Made It (New York: Knopf, 1973), xxxvi.

29. Bernstein, "Archive of American Television Interview."

30. Erik Christiansen, Channeling the Past: Politicizing History in Postwar America (Madison: University of Wisconsin, 2013), 141.

31. Martin Grams, The History of the Cavalcade of America (Kearney, NE: Morris, 1998); Freedoms Foundation of Valley Forge, "Freedoms Foundation of Valley Forge-America's School for Citizenship Education," http://www.freedomsfoundation.org/aboutUs.cfm, accessed April 24, 2009.

32. Bernstein, Inside Out, 222; Polonsky, You Are There Teleplays, 27.

33. Polonsky, You Are There Teleplays, 290; Bernstein, “Archive of American Television Interview"; Polonsky, "Archive of American Television Interview."

34. Walter Bernstein, "Between Us and Them, Suspicion Poisons the Air," Los Angeles Times, September 9, 2004, http://articles.latimes.com/2004/sep/09/opinion/oe-bernstein9, accessed April 15, 2013; Polonsky, "Archive of American Television Interview."

35. See Hollywood Democratic Committee Papers, Wisconsin Center for Film and Theater Research, Madison.

36. Clayton Knowles, "PCA Votes 74-Point Platform Embracing Wallace Policies," New York Times, January 19, 1948, 1; John Culver and John Hyde, American Dreamer: The Life and Times of Henry A. Wallace (New York: Norton, 2000), 433-34; Walter Bernstein, Inside Out, 245-46; James Chapman, "The Adventures of Robin Hood and the Origins of the Television Swashbuckler," Media History 17, no. 3 (2011): 274.

37. Bernstein, Inside Out, 245-46.

38. Chapman, "The Adventures of Robin Hood and the Origins of the Television Swashbuckler," 273; Walter Arnes, "Robin Hood Continues His Fast Galloping over Hill, Dale, Television," Los Angeles Times, October 6, 1957, G5.

39. Peter H. Brown, "Blacklist: The Black Tale of Turmoil in Filmland," Los Angeles Times, February 1, 1981, N3; Bernard Dick, Radical Innocence: A Critical Study of the Hollywood Ten (Lexington: University Press of Kentucky, 1989), 166-68, 203; "Ian McLellan Hunter, Screenwriter, Was 75," New York Times, March 7, 1991, http://www.nytimes.com/1991/03/07/obituaries/ ian-mclellan-hunter-screenwriter-was-75.html, accessed January 14, 2013.

40. Steve Neale, "Swashbucklers and Sitcoms, Cowboys and Crime, Nurses, Just Men and Defenders: Blacklisted Writers and TV in the 1950s and 1960s," Film Studies 7 (winter 2005): 83-84, 89-92. 


\section{Andrew Paul}

41. Neale, "Swashbucklers and Sitcoms, Cowboys and Crime, Nurses, Just Men and Defenders," 89-92; Steve Neale, "Pseudonyms, Sapphire and Salt: 'Un-American' Contributions to Television Costume Adventure Series in the 1950s," Historical Journal of Film, Radio and Television 23, no. 3 (2003): 247.

42. Ring Lardner, Jr., "Archive of American Television Interview," Archive of American Television, July 1, 1999, http://www.emmytvlegends.org/interviews/people/ring-lardner-jr, accessed April 16, 2013.

43. Lardner, "Archive of American Television Interview"; "Feared by the Bad, Loved by the Good," On the Media, July 23, 2010, radio broadcast, http://www.onthemedia.org/2010/jul/23/ feared-by-the-bad-loved-by-the-good/transcript/, accessed October 30, 2012.

44. Lardner, "Archive of American Television Interview."

45. For more on Hayek and neoliberal economics see Daniel Stedman Jones, Masters of the Universe: Hayek, Friedman, and the Birth of Neoliberal Politics (Princeton, NJ: Princeton University Press, 2012).

46. Neale, "Swashbucklers and Sitcoms, Cowboys and Crime, Nurses, Just Men and Defenders," 90.

47. Ibid., 89.

48. See "The Friar's Pilgrimage" in the second season, for example.

49. Paul Buhle and Dave Wagner, Hide in Plain Sight: The Hollywood Blacklistees in Film and Television, 1950-2002 (New York: Palgrave Macmillan, 2003), 86.

50. Ibid., 84.

51. E. J. Hobsbawm, Primitive Rebels: Studies in Archaic Forms of Social Movement in the 19th and 20th Centuries (Manchester: Manchester University Press, 1959), 24.

52. James Livingston, Pragmatism, Feminism, and Democracy: Rethinking the Politics of American History (New York: Routledge, 2001), 81.

53. Culver and Hyde, American Dreamer, 292.

54. Ibid., 301.

55. V. J. Jerome, Culture in a Changing World: A Marxist Approach (New York: New Century Publishers, 1947), 35-37; John Howard Lawson, The Hidden Heritage: A Rediscovery of the Ideas and Forces That Link the Thought of Our Time with the Culture of the Past (New York: Citadel Press, 1950).

56. Neale, "Swashbucklers and Sitcoms, Cowboys and Crime, Nurses, Just Men and Defenders."

57. For air dates: Neale, "Swashbucklers and Sitcoms, Cowboys and Crime, Nurses, Just Men, and Defenders"; "The Buccaneers," http://www.tv.com/shows/the-buccaneers-1956, accessed January 8, 2013.

58. In the comprehensive list of blacklistee credits that Neale has assembled for 1950s television, he has placed a question mark next to Waldo Salt for this episode; see Neale, "Swashbucklers and Sitcoms, Cowboys and Crime, Nurses, Just Men and Defenders," 95.

59. Peggy Phillips to Hannah Weinstein, Nov. 23, 1956, Waldo Salt Papers, box 120 folder 3, Charles Young Research Library, University of California Los Angeles.

60. See correspondence between Arthur Ruben, Ian McLellan Hunter, and Ring Lardner, Jr., Ian McLellan Hunter Papers, box 4 folder 17, Margaret Herrick Library, Los Angeles, CA; Research notes, Waldo Salt Papers, box 120 folder 3.

61. Research notes, Waldo Salt Papers, box 120 folder 3.

62. "Format Change for the Buccaneers," Waldo Salt Papers, box 120 folder 3.

63. See Alan Taylor, American Colonies (New York: Penguin Books, 2002); S. Max Edelson, Plantation Enterprise in Colonial South Carolina (Cambridge, MA: Harvard University Press, 2006).

64. Alan Nadel, Television in Black-and-White America: Race and National Identity (Lawrence: University Press of Kansas, 2005), 80-88, 143, 185.

65. Gordon Kahn, Hollywood on Trial: The Story of the 10 Who Were Indicted (New York: Boni \& Gaer, 1948), 98-99; "Writers' War Board Strongly Attacks Anglo-Saxon Myths," Hollywood Independent, October, 1945, box 4 folder 17, Hollywood Democratic Committee Papers.

66. Doherty, Cold War, Cool Medium, 3, 18.

67. Nikolas Rose, Powers of Freedom: Reframing Political Thought (New York: Cambridge University Press, 1999), 65.

68. Ibid., 277-79. 